International Review of Research in Open and Distributed Learning Volume 19, Number 5

November - 2018

\title{
The Inherent Tensions of "Instant Education": A Critical Review of Mobile Instant Messaging
}

\author{
Christoph Pimmer and Patient Rambe \\ University of Applied Sciences and Arts, Northwestern Switzerland FHNW, Central University of Technology, Bloemfontein, \\ South Africa
}

\begin{abstract}
This paper critically reviews literature on the role of Mobile Instant Messaging (MIM) applications, such as WhatsApp, in supporting learning and teaching practice. Using formal qualitative synthesis as its methodology, and dialectical theory as an analytical framework, our main objective was to identify tensions, affordances, constraints, and resolution strategies in educational uses of MIM. In contrast to prior work, the analysis offers a nuanced and complex picture of the use of MIM in learning and teaching settings. Instead of facilitating the creation of educational outcomes in a straightforward manner, the realities of MIM use are socially constructed and the subject of conflictual negotiations. The educational use of MIM requires users to navigate the interdependent dialectical tensions of immediacy versus delays (temporal dimension), intimacy versus detachment (relationship dimension) and task versus ludic orientation (intellectual dimension). The findings also reveal a number of behavioural and technical resolution strategies that users deploy to manage these tensions.
\end{abstract}

Keywords: instant messaging, mobile instant messaging, educational technology, mobile learning, social media, dialectical theory 


\section{Introduction}

\section{MIM and Education}

The use of Mobile Instant Messaging (MIM) applications such as WhatsApp, Snapchat, iMessage, KakaoTalk, and WeChat has grown tremendously in the last five years and presents a dominant mode of contemporary communication. For example, MIM application WhatsApp is rated as the third most popular social media platform after Facebook and YouTube (Statista, 2017). Contemporary MIM applications typically allow for both real-time and asynchronous communication. Their key features are alert mechanisms such as popups, sounds, or vibration that immediately notify users of incoming messages.

Surprisingly, relatively little is known about the role of instant messaging (IM) in learning and teaching. A few authors reviewed instant messaging before its proliferation on mobile platforms. For example, QuanHaase (2008) noted in her review of university students' IM behaviour that they used these platforms predominantly for social purposes, i.e., maintaining and nurturing distant and proximate social ties. Interestingly, in this early and non-mobile-focused analysis, several tensions came to the fore, which included students' "improper" writing while using IM and the detrimental effects of distraction and multitasking on their academic performance.

The use of IM on mobile devices (MIM) is under-researched; the only systematic review of MIM research is Tang and Hew's (2017). However, what is frequently acknowledged in the literature is MIM's ability to foster various forms of social presence in educational settings, and its informal use alone points to its relevance as part of students' personal learning environments. MIM's value in enabling knowledge development and cognitive outcomes in more formal education settings is less conclusive. In their review, Tang and Hew identified only a very small number of robust studies in educational settings. Of these seven studies, five showed positive outcomes and two showed no or even negative knowledge effects. However, similar to Quan-Haase's (2008) observations in her IM review, Tang and Hew identified a number of challenges. These included improper use of language, intrusion in private life, and irrelevant, inappropriate, and incoherent conversations. In this sense, IM and MIM have mixed effects and their use is associated with a number of tensions, ambiguities, and opposing characteristics that can alternately support and hinder students' academic work.

\section{Theoretical Framework}

To systematically uncover and understand these tensions, we used dialectical theory as an analytical framework because it is centred on understanding opposing dynamics. Dialectical perspectives originate from Baxter and Montgomery's (1996) dialectical theory. Its original focus was to study the dynamics of contradictions and their resolution in social relationships, such as the dialectical struggle between the relational opposites of being together versus being independent in a romantic relationship. These opposites cannot be seen as mutually exclusive either/or choices, but, in the sense of a resolution, require the partners

to address both simultaneously. This is not a one-time decision, but rather manifests as a continuous and ongoing process of negotiation (Montgomery, 1993). 
Beyond interpersonal relationships, dialectical approaches have been used to describe affordances and constraints of information technology. Broadly speaking, the notion of affordances does not describe physical or functional properties of a technology, but, from a user perspective, the range of perceived possibilities of what the objects could be used for (Gibson, 1986). In contrast, constraints are widely viewed as the ways in which technology users are held back from achieving a specific goal (Majchrzak \& Markus, 2012). Integrating these concepts with the theory of dialectical tensions, Gibbs, Rozaidi, and Eisenberg (2013) studied how the affordances of social media created tensions among distributed workers of an engineering division. Instead of simply increasing open communication and knowledge sharing, the use of social media prompted employees to manage dialectical tensions between visibility and invisibility, engagement and disengagement, and sharing and control.

In the field of technology-enhanced learning, dialectical approaches have seen only limited use. Perhaps the most prominent example is activity theory, which Engeström and Sannino (2010) conceive as dialectic in that the implementation of technology in a system produces contradictions that stem from sociocultural tensions, and which can be identified and addressed using their activity system model. However, although activity theory, particularly elements of Engeström and Sannino's model such as subjects, rules, and community, are popular in educational technology research, the ideas of contradictions and tensions from Engeström and Sannino's (2010) model are less commonly used. Dialectical approaches have also been used implicitly, for example in the concept of technological ambivalence, which has been used to describe tensions between the collaborative use of social media and the pressure that it generates to work individually and privately at the same time (Rambe \& Nel, 2015). The use of dialectical theory is also related to what Selwyn (2010) refers to as the critical study of educational technology. Broadly speaking, mainstream research in educational technology tends to conceive of digital technology as either a neutral, de-contextualised, and value-free medium that produces certain educational outcomes (Surry \& Baker, 2016), or as a space that favours a particular educational direction, an approach called soft determinism (Selwyn, 2012). In contrast, critical approaches do justice to the complex, compromised, constrained, and often conflicting realities of educational technology use, which is socially constructed and negotiated rather than predetermined (Selwyn, 2010).

\section{Approach and Methods}

\section{Research Question and Literature Search}

What follows from the initial literature review from above is that the proliferation of MIM, while being potentially beneficial for learning and teaching, brings about considerable tensions and contradictions that need to be better understood. Accordingly, we formulated the following research question:

What are the dialectical tensions in the educational use of mobile instant messaging, and what strategies do users apply to navigate and resolve these tensions? 
The goal of this research was thus not a systematic review of the effects of MIM, which has been carried out elsewhere (Tang \& Hew, 2017). Instead, we sought to better understand and conceptualise the underlying and opposing dynamics in the form of dialectical tensions by conducting a critical review. To build our arguments on a solid foundation, we conducted a systematic literature search using the databases PsycINFO, ERIC, Ovid, MEDLINE (via Ovid®), and Web of Science. We searched for the key term "mobile instant messaging," as well as names of applications (WhatsApp, iMessage, KakaoTalk, WeChat, BlackBerry Messenger, Facebook Messenger and Snapchat). In the Web of Science database, we refined the results by using the research area "education and educational research." We also carried out selective searches in Google Scholar and back-searched the reference sections of the articles we identified through those selective searches for further literature. We then reviewed abstracts using four main criteria (see Table 1); we retrieved and analysed only the articles that met these criteria.

Table 1

Eligibility Criteria for Studies

\begin{tabular}{ll}
\hline \multicolumn{1}{c}{ Criteria } & Description \\
\hline 1. Primary data & $\begin{array}{l}\text { Studies generated empirical data through qualitative, } \\
\text { quantitative, or mixed-methods designs. }\end{array}$ \\
\hline $\begin{array}{l}\text { 2. Sound \& } \\
\text { conceptually } \\
\text { grounded }\end{array}$ & $\begin{array}{l}\text { Study results were available, scientifically traceable, plausible, } \\
\text { and grounded in educational/instructional (or related social } \\
\text { science) concepts, theories, or frameworks. }\end{array}$ \\
\hline $\begin{array}{l}\text { 3. } \text { Learning and } \\
\text { teaching } \\
\text { activities }\end{array}$ & $\begin{array}{l}\text { Studies focused on the research and evaluation of concrete } \\
\text { learning or teaching activities (e.g., we excluded }\end{array}$ \\
\hline $\begin{array}{l}\text { 4. } \text { Use of mobile } \\
\text { instant } \\
\text { messaging } \\
\text { features }\end{array}$ & $\begin{array}{l}\text { Studies involved the use of MIM applications; we excluded } \\
\text { research that examined more traditional text messaging } \\
\text { applications, such as SMS or MMS. }\end{array}$ \\
\hline
\end{tabular}

\section{Data Analysis}

Twenty-one studies met our criteria for inclusion. To make sense of the predominantly qualitative research data in this emerging field of educational research, we used thematic analysis as our methodological approach to formal qualitative synthesis. In studies employing qualitative synthesis, findings are systematically interpreted through a series of expert judgments to represent the meaning of the collected work (Bearman \& Dawson, 2013). Thematic analysis involves repeated reading and analysis of texts and the identification of key themes and concepts across diverse studies. Here, we identified dialectical tensions, i.e., themes that contradicted or opposed one another, and associated affordances, constraints, and resolution strategies by reading and rereading the literature. The method was inductive in that individual 
tensions were not derived from previous literature but were identified directly from the data. However, the concepts of tensions (opposing poles), affordances, constraints, and resolution strategies were derived from the theory of dialectical tensions. In other words, while the analysis of the content was inductive, the methods were applied in a deductive manner. By identifying dialectical tensions through an interpretive review, we construed an analytical layer that extended beyond the themes described in the individual studies (Bearman \& Dawson, 2013). Per Bearman and Dawson's (2013) recommendations, the authors iteratively discussed emerging findings, and diverging interpretations were resolved upon discussion (Pope, Ziebland, \& Mays, 2000).

\section{Sample Characteristics}

In Table 2, we briefly summarise the key characteristics of the sample.

Table 2

Designs, Tools, and Settings of MIM Studies

\begin{tabular}{|c|c|}
\hline ory & Description \\
\hline & $\begin{array}{l}\text { Seventeen studies examined WhatsApp use. Other apps featured in } \\
\text { studies were KakaoTalk (Kim, Lee, \& Kim, 2014), Mxit (Botha \& } \\
\text { Butgereit, 2012; Butgereit, 2007; van Rooyen, 2010), and MSN and } \\
\text { Skype (Timmis, 2012). }\end{array}$ \\
\hline $\begin{array}{l}\text { Social } \\
\text { formation }\end{array}$ & $\begin{array}{l}\text { The } 21 \text { studies featured a number of } 23 \text { different social formations, the } \\
\text { most common being group learning designs }(n=17) \text {. In group learning } \\
\text { designs peers interacted in joint spaces exclusively among themselves } \\
(n=2) \text { or with educators }(n=15) \text {. In addition, in four studies one-to-one } \\
\text { conversations were reported between educator and learner; and in one } \\
\text { study between individual learners. (Two studies incorporated } \\
\text { individual and group learning designs, and in one study this was } \\
\text { unclear). }\end{array}$ \\
\hline $\begin{array}{l}\text { Degree of } \\
\text { formality }\end{array}$ & $\begin{array}{l}\text { In } 17 \text { of the } 21 \text { studies, the MIM activity formed an explicit part of formal } \\
\text { education settings. In four studies, the use of MIM in educational } \\
\text { settings was informal, i.e., not directly integrated with formal } \\
\text { educational activities. }\end{array}$ \\
\hline $\begin{array}{l}\text { Media } \\
\text { integration }\end{array}$ & $\begin{array}{l}\text { MIM learning and teaching activities were mainly linked with face-to- } \\
\text { face teaching, which resulted in blended learning designs ( } \mathrm{n}=14) \text {. Only } \\
\text { three studies examined exclusively digital/mobile educational settings, } \\
\text { and in another four studies this this was not discernible. }\end{array}$ \\
\hline
\end{tabular}


Course/ The most dominant educational subjects were computer science $(n=7)$, module four each of business, education, and health, and two each of mathematics and research methods. One study (Gachago et al., 2015) had three different educational subjects.

Education Seventeen of the 21 studies examined MIM in higher education. Two level studies involved students from secondary education (Botha \& Butgereit, 2012; Bouhnik \& Deshen, 2014; Butgereit, 2007), one focused on the nature of learning and supervision in work-related education (Henry et al., 2015), and in one study this was not discernible (Alabbasi, 2016).

\begin{tabular}{|c|c|}
\hline Location & $\begin{array}{l}\text { The studies had a broad geographical scope. Most studies ( } \mathrm{n}=12 \text { ) were } \\
\text { conducted in South Africa; other studies were conducted in Europe } \\
\text { (Castrillo, Martín-Monje, \& Bárcena, 2014; Timmis, 2012), the Middle }\end{array}$ \\
\hline & $\begin{array}{l}\text { East (Aburezeq \& Ishtaiwa, 2013; Alabbasi, 2016; Bouhnik \& Deshen), } \\
\text { and Asia (Kim et al., 2014; Lam, 2015; So, 2016). }\end{array}$ \\
\hline
\end{tabular}

\section{Results}

Three central pairs of oppositions emerged in the analysis of the data: immediacy versus delays, intimacy versus detachment, and task versus ludic orientation. These are summarised in Table 3, which presents the affordances and constraints associated with these tensions, as well as the strategies that learners and educators applied to resolve them.

Table 3

Overview of Tensions, Affordances, Constraints, and Resolution Strategies

\begin{tabular}{llll}
\hline Tensions & Affordances & Constraints & Resolution strategies \\
\hline Immediacy & Immediacy provides & Immediacy creates & Behavioural strategies: \\
vs. delays & logistical benefits & pressure on users to & Educators can foster \\
& (quicker access to & respond quickly. & immediacy through \\
& learning resources) & & providing guidelines on \\
& and mediates & response times, developing a \\
Temporal & development of & schedule for synchronous \\
dimension & shared goals, actions, & discussions, and enforcing \\
& and understanding. & delays by postponing
\end{tabular}


answers.

Delayed Delays cause frustration

conversations allow if learning conversations Technical strategy:

ongoing engagement are interrupted Educators and learners can

and widen mute alerts.

opportunities for

participation.

\begin{tabular}{|c|c|c|c|}
\hline $\begin{array}{l}\text { Intimacy vs. } \\
\text { detachment }\end{array}$ & $\begin{array}{l}\text { Intimacy involves } \\
\text { creation of closer } \\
\text { relationships between } \\
\text { learners and } \\
\text { educators. }\end{array}$ & $\begin{array}{l}\text { Intimacy is perceived as } \\
\text { an intrusion on privacy, } \\
\text { e.g., through obtrusive } \\
\text { pop-up features and } \\
\text { discussions during time } \\
\text { considered to be personal }\end{array}$ & $\begin{array}{l}\text { Technical strategy: Learners } \\
\text { limit intrusions by using } \\
\text { distinct channels for } \\
\text { personal and educational } \\
\text { discussions. }\end{array}$ \\
\hline \multirow{2}{*}{$\begin{array}{l}\text { Relationship } \\
\text { dimension }\end{array}$} & & $\begin{array}{l}\text { Educators are challenged } \\
\text { by the intimacy of } \\
\text { informal language }\end{array}$ & \\
\hline & $\begin{array}{l}\text { Detachment reflects } \\
\text { demands for private } \\
\text { spaces and non- } \\
\text { educational } \\
\text { commitments. }\end{array}$ & $\begin{array}{l}\text { Pronounced detachment } \\
\text { (in the form of } \\
\text { disengagement) is } \\
\text { perceived critically. }\end{array}$ & $\begin{array}{l}\text { Behavioural strategies: } \\
\text { Educators implement } \\
\text { language rules and sanctions } \\
\text { to avoid intimate/inadequate } \\
\text { conversations, and adhere to } \\
\text { office hours/pre-determined } \\
\text { schedules. }\end{array}$ \\
\hline $\begin{array}{l}\text { Ludic vs. } \\
\text { task } \\
\text { orientation }\end{array}$ & $\begin{array}{l}\text { A ludic orientation is } \\
\text { critical for immersion } \\
\text { in focused use of } \\
\text { MIM. }\end{array}$ & $\begin{array}{l}\text { Students and educators } \\
\text { are critical of an } \\
\text { abundance of playful and } \\
\text { socialising messages not } \\
\text { related to content. }\end{array}$ & $\begin{array}{l}\text { Behavioural strategy: } \\
\text { Educators define posting } \\
\text { requirements and evaluation } \\
\text { criteria regarding the quality } \\
\text { of content. }\end{array}$ \\
\hline $\begin{array}{l}\text { Intellectual } \\
\text { dimension }\end{array}$ & $\begin{array}{l}\text { Performativity in the } \\
\text { form of playfulness } \\
\text { and enactment of } \\
\text { existing relations }\end{array}$ & & $\begin{array}{l}\text { Technical strategy: } \\
\text { Educators "flag" key content. }\end{array}$ \\
\hline
\end{tabular}


assist in the creation

of shared experience.

Task orientation

results in focused

collaborative

learning.

\section{Immediacy Versus Delays: Timing Communication}

The communicative tension that learners and educators need to negotiate is situated on the continuum between immediacy and delays. This tension is rooted in the capacity of MIM to allow for near-tosynchronous communication as well as asynchronous and delayed communication.

Immediacy. One of the most salient qualities of instant messaging is its enablement of ad-hoc and real-time learning conversations, which are facilitated by visual (pop-up), acoustic (sound), and tactile (vibration) alerts. Accordingly, many studies emphasised the affordances of MIM to provide instantaneous learning communications stressing an added value, which is rather logistic than pedagogic (Aburezeq \& Ishtaiwa, 2013; Bere, 2012; Kim et al., 2014; Lam, 2015; Rambe \& Bere, 2013a; Ramukumba, 2015; Willemse \& Bozalek, 2015).

These logistical qualities included quick access to educator and peer assistance (Aburezeq \& Ishtaiwa, 2013; Bere, 2012; Willemse \& Bozalek, 2015), as illustrated in this student's statement: "[The use of a WhatsApp group] alerts you to [...] ideas from classmates instantly" (Bere, 2012, p. 10). This was deemed to be particularly important in work-based learning settings, where learners received immediate advice from their tutors in solving more complex problems (Willemse \& Bozalek, 2015). The mixed-method case study of Rambe and Bere (2013b) emphasised the use of MIM to provide South African IT students with prompt feedback in question-based consultations from peers and lecturers, which helped them solve problems and discuss academic issues. Groups of students from an educational technology course that used the MIM application KakaoTalk to solve pedagogical problems reported that the application provided opportunities to arrange ad-hoc learning conversations and to facilitate communication among distributed students (Kim et al., 2014). These students were contrasted with groups who used desktop applications and who found it difficult to schedule a time when all team members could log into their PCs. In addition to logistical benefits, Timmis (2012) identified the co-temporality of MIM-based learning conversations as a relevant mediator for the development of joint goals and actions and a shared understanding.

Although immediacy was considered an advantage in learning and teaching settings, it also created pressures on learners and educators to respond quickly. In this sense, "instant education" not only allows but demands immediate responses. For example, Bouhnik and Deshen (2014) described students' 
expectations that educators would be available 24/7. Another demand for immediacy in their study was voiced by educators who reported correcting mistakes as soon as they occurred to prevent them from "striking roots" and spreading in the digital spaces.

Delays. Immediate responses were often not possible due to situational and technical constraints, and users were required to balance their communication continuously between immediate and delayed responses. In other words, a considerable number of learning conversations were interrupted by users who dropped in and out, and who sometimes took up conversations after short breaks but other times after several hours (Timmis, 2012). Interrupted educational discourse was described as "annoying" in some studies; learners were often concerned about lack of immediate feedback from their instructors (Aburezeq \& Ishtaiwa, 2013) or frustrated with their unavailability during certain times (Rambe \& Bere, 2013b). In contrast, asynchronous features that allowed users to retrieve messages at a later point in time also created benefits (Rambe \& Bere, 2013a; Willemse, 2015). Rambe \& Bere (2013a) observed that delayed participation afforded multiple and temporally distributed interaction modes and thus widened the opportunities for student involvement. Delays also allowed for a deeper reflection on peers' ideas (Aburezeq \& Ishtaiwa, 2013; Rambe \& Bere, 2013a). For example, one of Aburezeq and Ishtaiwa's participants described how access to past conversations encouraged critical engagement and reflection: "Furthermore, I had to access previous discussions on WhatsApp platform to review some ideas before formulating my final answer. It is burdensome, but it is beneficial” (2013, p. 171).

The ambivalent ways in which learners perceive the interplay of immediacy and delays to create a different sense of connectedness is illustrated by a student who characterised the communication patterns of their group on KakaoTalk by using the seemingly contradictory statements of "all day long" versus "short time," which nicely showcases the perceived duality of communication practice: "I think our team discussed the topic all day long because we talked whenever we are available. Although it's short time" (Kim et al., 2014, p. 38).

Resolution strategies. In balancing the poles of immediacy versus delays, different behavioural and technical resolution strategies were developed and deployed. To keep conversations fluent, learners were asked to respond to instructor and peer questions within a given period of time (Aburezeq \& Ishtaiwa, 2013), or as quickly as possible (Rambe \& Bere, 2013a). Teachers also sought to adhere to reasonable response times (So, 2016). Moreover, lecturers developed schedules with sessions dedicated to synchronous discussions and information exchange as another approach to promoting immediate interaction (Ramukumba, 2015; So, 2016). In contrast, and as a means to develop temporal distance, educators also reported deliberately delaying their answers, answering flexibly (Bouhnik \& Deshen, 2014), and defining specific times to respond to learners' questions (Gachago, Strydom, Hanekom, Simons, \& Walters, 2015). To do so, they used technical measures that included muting the alert signals in their MIM applications (Bouhnik \& Deshen, 2014; Gachago, Strydom, Hanekom, Simons \& Walters, 2015). 


\section{Intimacy versus Detachment: Negotiating Social Relationships}

The second duality spans the continuum of intimacy versus detachment, i.e., social proximity versus distancing oneself from the educational community.

Intimacy. The observation that MIM affords high levels of intimacy, especially in contrast to other social media such as social network sites (Karapanos, Teixeira, \& Gouveia, 2016), was a predominant theme in many of the cited studies. MIM use was found to be conducive to the development of intimate, affective, and emotional learning spaces (Bere, 2012; Bouhnik \& Deshen, 2014; Castrillo et al., 2014; Henry et al., 2015; Kim et al., 2014; Timmis, 2012; van Rooyen, 2010), even in anonymous tutoring services (Butgereit, 2007). For example, Bouhnik and Deshen (2014) highlighted in their qualitative study that the advantages of WhatsApp groups reside in nurturing the social atmosphere and improving interpersonal relationships between educators and students. The high school teachers they interviewed felt that they would get to know their students better and learn about "what bothers them, what helps them" (Bouhnik \& Deshen, 2014, p. 226). Similarly, Castrillo et al. (2014) found several indicators of the development of group solidarity in their discourse analysis of WhatsApp-based language learning, including the reduction of social distance and the declaration of group membership. Kim et al. (2014) also identified emotional closeness as a key construct in their qualitative analysis. The facilitation of social proximity was deemed to be especially relevant in settings where learners suffered from professional isolation, such as the in-service teachers in Gachago et al.'s (2015) South African study.

The association between the co-construction of intimacy and MIM use was also identified in informal, "student-only" conversations. Timmis (2012) observed that the intimacy and affective behaviour that were nourished by shared history and co-produced social relations were nearly exclusively found in MIM use and not in the use of other digital communication tools.

Feelings of intimacy and closeness were, in part, rooted in the perception of MIM platforms as a personal space that afforded the use of informal language (Bere, 2012; Castrillo et al., 2014; Kim et al., 2014; Rambe \& Chipunza, 2013). As a student in Bere's study commented, "On WhatsApp I am free to express myself in anyway meaning that street language is acceptable and the platform is very informal" (2012, p. 13). This feeling was particularly evident in comparison with the formal language tied to the use of traditional learning management systems. However, in Bouhnik and Deshen's (2014) study, while learners tended to associate the day-to-day language used in instant messaging with intimacy and closeness, some educators felt challenged by their students' informal ways of expression, raising questions about whether to intervene, and, if so, how often.

Detachment. In opposition to intimacy, users and educators also perceived the use of MIM as an intrusion into their personal lives. While intrusive communication patterns did not present a burden to all users - as one educator commented, "I allowed my private space to be invaded but I did not mind" (Ramukumba, 2015, p. 8) - many studies revealed users' need for detachment from increasingly ubiquitous learning communities (Aburezeq \& Ishtaiwa, 2013; Bere, 2012; Bouhnik \& Deshen, 2014; Rambe \& Bere, 2013a; Smit, 2015; So, 2016; Willemse \& Bozalek, 2015). One reason that triggered users' needs for 
detachment were discussions that reached into time they perceived as personal. For example, Bere and Rambe (2016) observed that twice as many interactions took place between 6 and 11 p.m. than during the day. Moreover, and in contrast to the pull mechanisms of classic learning environments in which learners decide when and how to engage, the push messages associated with MIM use were perceived to be intrusive (Bere, 2012).Intrusion also manifested in terms of inappropriate content, perhaps most dramatically in the South African Dr. Math project, in which online tutors received numerous sexual propositions from pupils in the anonymous conversations (Butgereit, 2007).

The tension between intimate conversations and the need for withdrawal was especially observed in more mature learners (Aburezeq \& Ishtaiwa, 2013; Bere, 2012; Rambe \& Bere, 2013a; Willemse \& Bozalek, 2015) and in teachers, especially if they had many groups to moderate and if conversations took place during late hours (Bouhnik \& Deshen, 2014). However, some learners also criticised that other users' detachment was too pronounced, especially for the ones with very limited participation (Aburezeq \& Ishtaiwa, 2013).

Resolution strategies. Some users managed the tensions of intimacy and detachment by implicitly restricting their conversation times to office schedules (Castrillo et al., 2014) or to pre-arranged conversation times (Willemse \& Bozalek, 2015). This strategy is not only reflective of users' need to distance themselves from the learning community but also discloses the perception of MIM-based learning activities as explicit and formal educational practices. Intimacy and detachment were also managed by the selection of digital channels (Henry et al., 2015; Timmis, 2012). For example, Timmis (2012) observed that students tended to use separate spaces for their university and private communications to maintain these preestablished boundaries. Another way to protect the privacy of learners and educators was the establishment of guidelines and sanctions. In the Dr. Math project, the tutors were not allowed to reveal any information regarding their age, sex, and location (Butgereit, 2007). Students were also warned and even removed from the system if they used inappropriate language. As an additional control, textual conversations were recorded and spot-checked by administrators (Botha \& Butgereit, 2012).

\section{Task Versus Ludic Orientation: Managing the Depth of Intellectual Engagement}

The third tension that was reinforced through the educational appropriation of MIM and that needed to be addressed by learners and educators was the opposition between task orientation, in the sense of focused cognitive or meta-cognitive reasoning, and ludic orientation, a less profound intellectual engagement that resembles forms of playing and socialising.

Task orientation. A number of the studies we examined reported focused learning in MIM spaces, mostly based on conversation analysis and interviews (Henry et al., 2015; Kim et al., 2014; Lam, 2015; Rambe \& Bere, 2013a; So, 2016; Timmis, 2012; Willemse, 2015). For example, in their content analysis, Rambe and Bere (2013a) identified critical engagement with learning resources. This finding was corroborated through post-surveys, in which the majority of students associated the academic use of WhatsApp with knowledge creation and deep reflection. In Kim et al.'s (2014) study, students deemed MIM conversations to allow for sufficient time to review the contributions of other learners and to provide thoughtful feedback, especially compared with face-to-face discussions. Even in peer-to-peer learning 
settings not prescribed by educators, students engaged in MIM to discuss content and task-related issues (Lam, 2015; Timmis, 2012), for example carrying out mathematical calculation exercises (Lam, 2015). In some studies, focused engagement resulted in enhanced levels of cognition and knowledge, as highlighted in Tang and Hew's review (2017). One example is So's (2016) experimental work, which examined the effects of a WhatsApp group used to provide short multimedia materials and to facilitate interaction between learners and the lecturer in addition to classroom-based lectures. The intervention group scored significantly higher in the post-test compared with the control group, which used WhatsApp only for administrative purposes.

Ludic orientation. In contrast to promoting cognitive and metacognitive learning activities, considerable parts of the conversations in other studies tended to be less focused, involving socialising and playing (Aburezeq \& Ishtaiwa, 2013; Bouhnik \& Deshen, 2014; Gachago et al., 2015; Kim et al., 2014). The tension was especially evident in Gachago et al.'s (2015) study, where, despite the efforts of the educator to keep the conversations strictly academic, the space became increasingly social. Aburezeq and Ishtaiwa (2013) noted that in their study nearly half of all postings had fewer than 20 words and were based on brief and quick interactions rather than on reflective, critical, or deep thoughts. Kim et al. (2014) affirmed these tendencies towards playfulness and socialising in the quantitative content analysis of their mixed-method study. They found that MIM (and also desktop-based IM) groups were associated with higher levels of social and affective communication and with fewer cognitive and metacognitive interactions compared with the bulletin board groups. Their qualitative analysis indicated a lack of recursive and convergent utterances, with some of the learners in the MIM groups tending to simply state their opinions without reviewing or considering others' posts.

One reason offered for this tension is the implementation in formal education settings of a private tool (MIM) that is often used for hedonic purposes (Aburezeq \& Ishtaiwa, 2013; Willemse \& Bozalek, 2015). One learner characterised WhatsApp as "a toy for socializing and having fun, it is not for learning" (Aburezeq \& Ishtaiwa, 2013, p. 173). In addition, learners underlined the distractive potential of MIM due to its tempting proximity to other entertaining mobile phone applications, such as social network sites (Aburezeq \& Ishtaiwa, 2013). Another reason for these extraneous conversations lies in learners' ubiquitous use of MIM. Instead of concentrating on the learning activity, MIM is embedded in everyday life, and the associated multitasking is likely to result in a less focused cognitive engagement, as this student suggests: "These days I can easy [sic] post and get answers on WhatsApp even when I am shopping if I see or hear anything confusing related to my studies" (Bere, 2012, p. 11).

The educational implications of messages with playful and socialising content were perceived ambiguously. In part, messages that were not directly relevant to education were criticised by learners (Aburezeq \& Ishtaiwa, 2013) and deemed by educators to be upsetting (Bouhnik \& Deshen, 2014). However, drawing on content analysis, some authors observed that playful and extraneous discussions, albeit lacking strong intellectual qualities, can be viewed as a necessary social immersion in the productive use of MIM and can thus lay a foundation for its more intellectual use (Rambe \& Bere, 2013b). Similarly, Timmis (2012), who 
found significant indictors for playfulness and socialising in her discourse analysis, concluded that the creation and maintenance of a shared social experience is a relevant component of collaborative learning.

Resolution strategies. Behavioural resolution strategies that educators used to strike the balance between ludic and task orientation, and particularly, to orient learners towards a more focused and productive engagement, were the development of specific posting requirements and evaluation criteria (Aburezeq \& Ishtaiwa, 2013; Gachago et al., 2015). In Aburezeq and Ishtaiwa's (2013) interview study, learners' messages were required to reflect the course content and include new ideas, reflections, opinions, and critical thinking beyond mere description or summary. Learners in this study found the established criteria relevant and tied them to deeper levels of reflection and critical thinking. As a technical strategy, educators in Gachago et al.'s (2015) study flagged key discussions with emoticons. This allowed learners who did not participate in the socialising discussions, and who accessed WhatsApp only occasionally, to review the content and identify central information in an efficient manner.

\section{Discussion}

Our review and analysis of the literature has revealed a nuanced picture of the use of MIM in learning and teaching settings. By describing the conflicting dynamics of educational use of MIM, it adds to prior work which simply conceives the affordances of MIM to be "temporal, user-friendly, minimal cost, and multimodality features" and which explains its convenience as permitting users to "easily chat with peers or teachers anytime and anywhere they prefer" (Tang \& Hew, 2017, p. 100). In contrast, our findings suggest that instead of learning in a convenient and "straightforward" manner, both learners and educators need to navigate dialectical tensions that relate to time, relationship, and intellectual depth. This research has shown how the idiosyncrasy of MIM shapes, affords, and confines the ways in which learning and teaching play out, and, in the same way, how educational benefits are realised. What follows is that, despite the perception of MIM platforms as hugely popular low threshold applications (TLT Group, 2015), MIM is not easily implemented in more formal learning and teaching settings.

The effective navigation of tensions and opposing forces identified in this study requires users to develop a new set of skills that reaches far beyond the technical aspects of using mobile devices and applications. Balancing issues of timing, managing social distance, and weighing task against ludic engagement necessitates competencies that are not considered in classic media literacy definitions that typically incorporate the access, analysis, evaluation, and creation of content (Livingstone, 2004; Redecker, 2017). The skills to manage these tensions in the use of MIM spaces do not only play out at an individual level but need to be negotiated and calibrated collectively (e.g. in a group space), which can be a complex and conflictual process. For example, Pimmer, Mhango, Mzumara, and Mbvundula (2017) found that one of the prevailing challenges in the use of WhatsApp groups was the ongoing negotiation and reconciliation of users' divergent expectations regarding social versus task-oriented use of the space. What complicates this 
process further is that the poles which create these tensions are neither valuable nor damaging by themselves. Instead, they have unique qualities that cannot be played off against one another.

In contrast with the broader field of mobile learning, in which instructionist, transmissive, and nonconversational educational approaches have prevailed to date (Frohberg, Göth, \& Schwabe, 2009; Pimmer, Mateescu, \& Gröhbiel, 2016), the main route for learning and teaching in the MIM settings we reviewed was centred on social interaction. Given its strong capacity to develop and maintain a social presence in learning and teaching settings, MIM can be especially valuable in contexts in which the development, strengthening, and maintenance of social ties is central, as in the initial phase of online learning described in Salmon's (2003) five step model of e-moderation. According to Salmon, at this stage, moderators should familiarise students with the online environment through socialisation and provide bridges between sociocultural aspects of offline and online learning environments in ways that increase familiarity with peers and reduce social distance among them. Beyond a "sequential" perspective, socialising can be conceived as an inherent part of effective learning itself. This is reflected, for example, in the "social presence" dimension of the Community of Inquiry theory (Rourke, Anderson, Garrison, \& Archer, 2007), and, even more so, in the "participation" metaphor, in which the main route of learning is understood as growing into a community of practice (Lave \& Wenger, 1991; Paavola, Lipponen \& Hakkarainen, 2004).

Our study on the educational use of MIM technologies suggests several directions for future research. Our findings represent a snapshot in time; the rapid transformation of MIM technology and associated communication practices alone necessitate further research. For example, calling and voice notes are new functionalities that were recently added to a number of MIM applications, but which have not been addressed in the corpus of studies we examined. Another area that requires further exploration is the professionalisation of MIM-based tutoring. A recent BBC report describes an emerging tutoring industry based on "WhatsApp-style instant messaging environments." They highlight the example of "Snapask," which connects about 5,000 tutors with 100,000 students from Hong Kong, Taiwan, and Singapore. Students raise questions and the software matches them immediately with a tutor for an instant learning session (Jackson, 2016).

From a methodological perspective, the current body of literature consists primarily of qualitative research, some descriptive quantitative investigations, and a very limited number of studies that incorporate experimental designs. We thus agree with Tang and Hew (2017) that there is an obvious need for more rigorous quantitative research designs that more systematically and rigorously compare, for example, the differences between MIM and other communication modes. However, in line with dialectical theory, we argue that there is also a need for more thick and rich descriptions (Geertz, 1973), which further our understanding of the dialectical dynamics, especially how, in the course of MIM use, the relationship between oppositional forces may change. This could, for example, play out in the sense of a helical model, whereby the response to one dialectical pole creates pressure to attend to the opposite pole and, in consequence, the relationship pair cycles back and forth over time but never reaches precisely the same place as before (Baxter, 2003). Applied to MIM, this can be addressed, for example, by an examination that explores how the relationship between ludic and task orientation changes over time. 


\section{Conclusions}

This study has sought to contribute to the conceptualisation of a more fine-grained understanding of the conflicting and negotiated realities of the use of MIM in learning and teaching settings. One of its main contributions is the establishment of a framework that shows how the educational affordances and constraints of MIM unfold in the ways in which learners and educators navigate the dialectical tensions of immediacy versus delays, intimacy versus detachment, and task versus ludic orientation. This framework might not only help readers to make sense of learning in current mobile instant messaging environments, but it could also help to inform our understanding about the emerging practice of ubiquitous messaging, as several large tech companies are in the process of offering unified mobile and desktop messaging applications.

Moreover, the dialectical theory of Baxter and Montgomery (1996), proved a helpful framework with which to critically analyse and problematise the use of educational technology, an approach that might also help scholars in the exploration of other fields of technology-enhanced learning. 


\section{References}

Aburezeq, I. M., \& Ishtaiwa, F. F. (2013). The impact of WhatsApp on interaction in an Arabic language teaching course. International Journal of Arts \& Sciences, 6(3), 165-180. . Retrieved from http://universitypublications.net/ijas/0603/pdf/F3N281.pdf

Alabbasi, D. (2016, April). WhatsApp, agency and education: The case of female Saudi teachers. Paper presented at the DEANZ Biennial Conference: Charting Flexible Pathways in Open and Distance Education, Hamilton, NZ. Retrieved from http://flanz.org.nz/conference-proceedings

Baxter, L. A. (2003). Dialectical theory. International encyclopedia of marriage and family. Retrieved from http://www.encyclopedia.com/doc/1G2-3406900109.html

Baxter, L. A., \& Montgomery, B. M. (1996). Relating: Dialogues and dialectics. New York: Guilford Press. Retrieved from http://psycnet.apa.org/record/1996-98195-000

Bearman, M., \& Dawson, P. (2013). Qualitative synthesis and systematic review in health professions education. Medical Education, 47(3), 252-260. doi: 10.1111/medu.12092

Bere, A. (2012, November). A comparative study of student experiences of ubiquitous learning via mobile devices and learner management systems at a South African university. Paper presented at the proceedings of the 14th Annual Conference on World Wide Web Applications, Durban, South Africa. Retrieved from http://erepo.usiu.ac.ke/handle/11732/305

Bere, A., \& Rambe, P. (2016). An empirical analysis of the determinants of mobile instant messaging appropriation in university learning. Journal of Computing in Higher Education, 28(2), 72-198. doi: $0.1007 / \mathrm{s} 12528-016-9112-2$

Botha, A., \& Butgereit, L. (2012). Dr Math: A mobile scaffolding environment. International Journal of Mobile and Blended Learning, 4(2), 15-29. doi: 10.4018/jmbl.2012040102

Bouhnik, D., \& Deshen, M. (2014). WhatsApp goes to school: Mobile instant messaging between teachers and students. Journal of Information Technology Education: Research, 13, 217-231. Retrieved fromhttp://www.jite.org/documents/Vol13/JITEv13ResearchP217-231Bouhniko601.pdf

Butgereit, L. (2007). Math on Mxit: The medium is the message. Paper presented at the 13th Annual National Congress of the Association for Mathematics Education of South Africa (AMESA), White River, South Africa. Retrieved from http://researchspace.csir.co.za/dspace/handle/10204/1785

Castrillo, M. D., Martín-Monje, E., \& Bárcena, E. (2014). New forms of negotiating meaning on the move: The use of mobile-based chatting for foreign language distance learning. IADIS International Journal, 12(2), 51-67. Retrieved from www.iadisportal.org/ijwi/papers/2014121204.pdf

Engeström, Y., \& Sannino, A. (2010). Studies of expansive learning: Foundations, findings and future challenges. Educational Research Review, 5(1), 1-24. doi: 10.1016/j.edurev.2009.12.002 
Frohberg, D., Göth, C., \& Schwabe, G. (2009). Mobile learning projects: A critical analysis of the state of the art. Journal of Computer Assisted Learning, 25(4), 307-331. doi: 10.1111/j.13652729.2009.00315.x

Gachago, D., Strydom, S., Hanekom, P., Simons, S., \& Walters, S. (2015). Crossing boundaries: Lecturers' perspectives on the use of WhatsApp to support teaching and learning in higher education. Progressio: South African Journal for Open and Distance Learning Practice, 37(1), 172-187. Retrieved from https://journals.co.za/content/progress/37/1/EJC180393

Geertz, C. (1973). The interpretation of cultures: Selected essays (Vol. 5019). New York: Basic Books. Retrieved from https://monoskop.org/images/5/54/Geertz Clifford The Interpretation of Cultures Selected Essays.pdf

Gibbs, J. L., Rozaidi, N. A., \& Eisenberg, J. (2013). Overcoming the "ideology of openness": Probing the affordances of social media for organizational knowledge sharing. Journal of Computer-Mediated Communication, 19(1), 102-120. doi: 10.1111/jcc4.12034

Gibson, J. J. (1986). The ecological approach to visual perception. Hillsdale, New Jersey: Lawrence Erlbaum.

Henry, J., Winters, N., Lakati, A., Oliver, M., Geniets, A., Mbae, S. M., \& Wanjiru, H. (2015). Enhancing the supervision of community health workers with WhatsApp mobile messaging: Qualitative findings from 2 low-resource settings in Kenya. Global Health: Science and Practice, 4(2), 311325. doi: $10.9745 /$ GHSP-D-15-00386

Jackson, T. (2016, June 8). Tutors become part of the app culture. BBC News. Retrieved from http://www.bbc.com/news/business-36461191

Karapanos, E., Teixeira, P., \& Gouveia, R. (2016). Need fulfillment and experiences on social media: A case on Facebook and WhatsApp. Computers in Human Behavior, 55(B), 888-897. doi: $\underline{0.1016 / j . c h b .2015 \cdot 10.015}$

Kim, H., Lee, M., \& Kim, M. (2014). Effects of mobile instant messaging on collaborative learning processes and outcomes: The case of South Korea. Journal of Educational Technology \& Society, 17(2), 31-42. Retrieved from http://www.jstor.org/stable/jeductechsoci.17.2.31

Lam, J. (2015). Collaborative learning using social media tools in a blended learning course. In S.K.S. Cheung et al. (Eds.), Hybrid learning: Innovation in educational practices (pp. 187-198). Switzerland: Springer. doi: 10.1007/978-3-319-20621-9 15 
Lave, J., \& Wenger, E. (1991). Situated learning: Legitimate peripheral participation. Cambridge: University of Cambridge Press.

Livingstone, S. (2004). What is media literacy? Intermedia, 32(3), 18-20. Retrieved from http://eprints.lse.ac.uk/1027/

Majchrzak, A., \& Markus, M. L. (2012). Technology affordances and constraints in management information systems (MIS). In E. Kessler (Ed.), Sage Publications, Forthcoming. Retrieved from https://ssrn.com/abstract=2192196

Montgomery, B. M. (1993). Relationship maintenance versus relationship change: A dialectical dilemma. Journal of Social and Personal Relationships, 1O(2), 205-223.

Paavola, S., Lipponen, L., \& Hakkarainen, K. (2004). Models of innovative knowledge communities and three metaphors of learning. Review of Educational Research, 74(4), 557-576. doi: 10.3102/00346543074004557

Pimmer, C., Mateescu, M., \& Gröhbiel, U. (2016). Mobile and ubiquitous learning in higher education settings. A systematic review of empirical studies. Computers in Human Behavior, 63, 490-501. doi: 10.1016/j.chb.2016.05.057

Pimmer, C., Mhango, S., Mzumara, A., \& Mbvundula, F. (2017). Mobile instant messaging for rural community health workers: A case from Malawi. Global Health Action, 1O(1). doi: 10.1080/16549716.2017.1368236

Pope, C., Ziebland, S., \& Mays, N. (2000). Qualitative research in health care: analysing qualitative data. British Medical Journal, 320(7227), 114-116. doi: 10.1136/bmj.320.7227.114

Quan-Haase, A. (2008). Instant messaging on campus: Use and integration in university students' everyday communication. The Information Society, 24(2), 105-115. doi: 10.1080/01972240701883955

Rambe, P., \& Bere, A. (2013a). Using mobile instant messaging to leverage learner participation and transform pedagogy at a South African University of Technology. British Journal of Educational Technology, 44(4), 544-561. doi: 10.1111/bjet.12057

Rambe, P., \& Bere, A. (2013b, June). Using social embeddedness to explore ubiquitous learning in mobile environments at a South African University of Technology. Paper presented at the International Conference on e-Learning, Cape Town. Retrieved from https://search.proquest.com/openview/17c5535bb6818eeebd335ca862cd4172/1 
Rambe, P., \& Chipunza, C. (2013, September). Using mobile devices to leverage student access to collaboratively-generated resources: A case of WhatsApp instant messaging at a South African University. Paper presented at the International Conference on Advanced Information and Communication Technology for Education (ICAICTE 2013), Hainan. Retrieved from https://www.atlantis-press.com/proceedings/icaicte-13

Rambe, P., \& Nel, L. (2015). Technological utopia, dystopia and ambivalence: Teaching with social media at a South African university. British Journal of Educational Technology, 46(3), 629-648. doi: 10.1111/bjet.12159

Ramukumba, M. (2015). Using mobile devices in supervision of graduate research in distance education: A personal journey. In H. T. Brown \& J. H. van der Merwe (Eds.), The Mobile Learning Voyage From Small Ripples to Massive Open Waters: 14th World Conference on Mobile and Contextual Learning, mLearn 2015, Venice, Italy, October 17-24, 2015, Proceedings (pp. 1-14). Cham: Springer International Publishing. doi: 10.1007/978-3-319-25684-9_1

Redecker, C. (2017). European Framework for the Digital Competence of Educators: DigCompEdu. In Y. Punie, (Ed.). EUR 28775 EN. Publications Office of the European Union, Luxembourg. doi: $10.2760 / 159770$.

Rourke, L., Anderson, T., Garrison, D. R., \& Archer, W. (2007). Assessing social presence in asynchronous text-based computer conferencing. The Journal of Distance Education/Revue de l'Éducation à Distance, 14(2), 50-71. Retrieved from http://hdl.handle.net/2149/732

Salmon, G. (2003). E-moderating: The key to teaching and learning online. London: Routledge.

Selwyn, N. (2010). Looking beyond learning: Notes towards the critical study of educational technology. Journal of Computer Assisted Learning, 26(1), 65-73. doi: https://doi.org/10.1111/j.13652729.2009.00338.x

Selwyn, N. (2012). Making sense of young people, education and digital technology: The role of sociological theory. Oxford Review of Education, 38(1), 81-96. doi: 10.1080/03054985.2011.577949

Smit, I. (2015, October). WhatsApp with learning preferences? Paper presented at the Frontiers in Education Conference (FIE), Washington, DC. Retrieved from https://www.computer.org/csdl/proceedings-article/2015/fie/07344.366/12OmNzFdt3Q

So, S. (2016). Mobile instant messaging support for teaching and learning in higher education. The Internet and Higher Education, 31, 32-42. doi: 10.1016/j.iheduc.2016.06.001 
Statista. (2017). Most famous social network sites worldwide as of August 2017, ranked by number of active users (in millions). Retrieved from https://www.statista.com/statistics/272014/globalsocial-networks-ranked-by-number-of-users/

Surry, D. W., \& Baker, F. W. (2016). The co-dependent relationship of technology and communities. British Journal of Educational Technology, (47)1, 13-28. doi: 10.1111/bjet.12349

Tang, Y., \& Hew, K. F. (2017). Is mobile instant messaging (MIM) useful in education? Examining its technological, pedagogical, and social affordances. Educational Research Review, 21, 85-104. doi: 10.1016/j.edurev.2017.05.001

Timmis, S. (2012). Constant companions: Instant messaging conversations as sustainable supportive study structures amongst undergraduate peers. Computers \& Education, 59(1), 3-18. doi: 10.1016/j.compedu.2011.09.026

TLT Group. (2015). Low threshold applications [Blog post]. Retrieved from https://tltgroup.wordpress.com/low-threshold-applications/

van Rooyen, A. A. (2010). Integrating MXit into a distance education Accounting module. Progressio, 32(2), 52-64. Retrieved from https://journals.co.za/content/progress/32/2/EJC122762

Willemse, J. (2015). Undergraduate nurses reflections on Whatsapp use in improving primary health care education. Curationis, 38(2), 1-7. doi: 10.4102/CURATIONIS.v38i2.1512

Willemse, J., \& Bozalek, V. (2015). Exploration of the affordances of mobile devices in integrating theory and clinical practice in an undergraduate nursing programme. Curationis, 38(2), 1-10. doi: 10.4102/CURATIONIS.v38i2.1510

\section{Athabasca} University

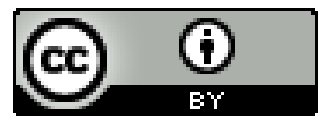

